\title{
NATURE OF ANAEMIA IN RHEUMATOID ARTHRITIS II. SURVIVAL OF TRANSFUSED ERYTHROCYTES IN PATIENTS WITH RHEUMATOID ARTHRITIS
}

\author{
BY \\ W. R. M. ALEXANDER, J. RICHMOND, L. M. H. ROY, AND J. J. R. DUTHIE \\ From the Rheumatic Unit, Northern General Hospital, Edinburgh
}

(RECEIVED FOR PUBLICATION JULY 11, 1955)

In a recent report, Roy, Alexander, and Duthie (1955) reviewed the literature on the characteristics of anaemia in rheumatoid arthritis and described abnormalities of iron metabolism in this disease. It was shown that the anaemia did not present the typical features of iron-deficiency and that there was no evidence of impaired absorption of iron from the gut in the majority of cases. Decreased survival of erythrocytes transfused from healthy donors to patients with active rheumatoid arthritis had been observed, and it was suggested that a reduced lifespan of the patient's own red cells might be a factor in the production of anaemia.

There are few reports on the fate of transfused red cells in rheumatoid arthritis. Brown, Hayward, Powell, and Witts (1944) found that cell survival was normal in one patient with "severe disease". It was not made clear if this implied that evidence of active inflammation was still present. Mollison and Paterson (1949) gave two transfusions to each of two patients suffering from rheumatoid arthritis. Cells used for the first transfusion in each case were incubated in vitro with serum containing $\mathrm{Rh}$-blocking antibody and in both instances survival of the transfused cells was markedly reduced. Both patients were transfused again with cells which had not been exposed to blocking antibody. In one case rapid destruction was again observed, but in the other, cell survival was of normal duration.

Since the start of the present investigation two further reports have appeared. Freireich, Ross, Bayles, Emerson, and Finch (1954) measured the survival of transfused cells in patients with rheumatoid arthritis and found it to be decreased, destruction being most marked in patients with active disease. Bunim (1954), who used ${ }^{51} \mathrm{Cr}$. to measure the survival of patient's own red cells, stated that an increased rate of destruction was recorded in patients with active rheumatoid arthritis.

The present study was designed to investigate more thoroughly the possibility that abnormal destruction of red cells might be a factor in the causation of anaemia in rheumatoid arthritis. The first part of the report deals with studies of the survival of cells from healthy donors in patients with active disease and varying degrees of anaemia.

It was felt that abnormally rapid destruction of healthy red cells might not necessarily imply that the patients' own red cells were being destroyed at the same rate. The second part of the report records the results of experiments designed to compare the survival of cells from a rheumatoid patient with that of cells from a healthy donor in the same recipient; recipients with clear-cut evidence of active rheumatoid disease were closen. Such a comparison does not provide any measure of the life-span of the recipient's own red cells, but it was considered important to ascertain whether any difference existed between the survival of healthy cells and rheumatoid cells in the rheumatoid patient.

In addition, a comparison has been made of the survival of healthy red cells before and during the administration of ACTH to rheumatoid patients. Similar observations have been recorded before and during haematological improvement induced by the administration of iron by the intravenous route.

\section{Materials and Methods}

Recipients.-Nineteen patients were selected for transfusion. All were under treatment as in-patients and suffered from well-established rheumatoid disease involving many joints. All were in an active phase of the disease with a raised erythrocyte sedimentation rate and varying degrees of anaemia. Details of age, sex, and duration of disease are included in Table I (opposite) and Table II (overleaf).

During the period of investigation all patients underwent a basic regime of treatment consisting of general rest, splinting of painful joints, analgesics, and physiotherapy.

Transfusions were given to two healthy males as a control on the technique employed.

Donors.-Normal blood of Group $O$ and suitable rhesus group was supplied by the Blood Transfusion Service, Royal Infirmary, Edinburgh. 
Blood from rheumatoid donors was obtained from volunteers among the patients in the Rheumatic Unit, Northern General Hospital, Edinburgh. The criteria for selection of donors were as for recipients, but only individuals with moderate degrees of anaemia (more than 75 per cent. $\mathrm{Hb}$ ) were asked to donate blood.

Storage of Blood before Transfusion.-Blood was stored at $4^{\circ} \mathrm{C}$. in acid-citrate-dextrose for $48 \mathrm{hrs}$ after withdrawal. Red cells were packed within $2 \mathrm{hrs}$ of transfusion. Direct compatibility tests were made by the Blood Transfusion Service.

Technique for Measurement of Survival of Transfused Red Cells.-The differential agglutination technique evolved by Ashby (1919) was used with certain modifications.

To $1 \mathrm{ml}$. physiological saline was added $20 \mathrm{c.mm}$. capillary blood obtained by ear prick. $0.3 \mathrm{ml}$. of this suspension was mixed with an aliquot of appropriate antiserum (undiluted) in a $75 \times 10 \mathrm{~mm}$. test tube and kept at room temperature for $1 \mathrm{hr}$. The suspension was centrifuged at 1,000 r.p.m. for $1 \mathrm{~min}$. and thereafter tapped gently until the agglutinate was released from the bottom of the tube and an even suspension in the supernate obtained. A sample of the supernate was removed with a Pasteur pipette and the number of free red cells counted in a Neubauer chamber.

All recipients belonged to blood groups $\mathrm{A}, \mathrm{B}$, or $\mathrm{AB}$, with one exception (in which Anti-D serum was used to measure survival of Group $O \mathrm{Rh}$-negative cells in a Group $O$ Rh-positive recipient). Potent Anti-A or Anti-B sera, supplied by the Blood Transfusion Officer, were used to produce agglutination of the recipient's cells. Before transfusion the appropriate anti-serum was tested on at least two occasions with the cells of the prospective recipient. A free cell count after agglutination of $10,000 / \mathrm{c} . \mathrm{mm}$. or less was considered satisfactory.

Where possible, surviving cells were counted at daily intervals for 4 days after transfusion. Subsequent counts were made approximately twice weekly. The number of surviving cells was expressed as a percentage of the highest count recorded during the first 4 days. Survival was measured from the day on which this count was recorded.

Haemoglobin Concentration (Hb) was measured in a colorimeter as alkali haematin. Results are expressed as percentages of $14.8 \mathrm{~g} . / 100 \mathrm{ml}$. whole blood.

Erythrocyte Sedimentation Rate (E.S.R.) was measured in Westergren tubes. Dry ammonium/potassium oxalate mixture was used as an anti-coagulant.

\section{Results}

Survival of Red Cells from Healthy Donors in Patients suffering from Active Rheumatoid Arthritis.-Details of the age, sex, and clinical status of the eighteen patients before transfusion are included in Table I.

TABLE I

SURVIVAL OF CELLS FROM HEALTHY DONORS IN EIGHTEEN PATIENTS WITH RHEUMATOID ARTHRITIS

\begin{tabular}{|c|c|c|c|c|c|c|c|}
\hline \multirow{2}{*}{$\begin{array}{l}\text { Case } \\
\text { No. }\end{array}$} & \multirow{2}{*}{ Age } & \multirow{2}{*}{ Sex } & \multirow{2}{*}{$\begin{array}{c}\text { Duration of } \\
\text { Disease } \\
\text { (yrs) }\end{array}$} & \multicolumn{2}{|c|}{ Before Transfusion } & \multirow{2}{*}{$\begin{array}{c}\text { Volume } \\
\text { Transfused } \\
\text { (pints) }\end{array}$} & \multirow{2}{*}{$\begin{array}{c}\text { Mean Survival } \\
\text { Time } \\
\text { (days) }\end{array}$} \\
\hline & & & & $\mathrm{Hb}$ (per cent.) & E.S.R. $(\mathrm{mm} . / \mathrm{hr})$ & & \\
\hline 1 & 75 & $\mathbf{F}$ & 1 & 73 & 104 & 2 & $16 \cdot 4$ \\
\hline 2 & 48 & $\mathbf{F}$ & 12 & 62 & 52 & 2 & $19 \cdot 7$ \\
\hline 3 & 52 & $\mathbf{M}$ & 4 & 60 & 37 & 2 & $17 \cdot 9$ \\
\hline 4 & 60 & $\mathbf{M}$ & 2 & 52 & 124 & 2 & $7 \cdot 8$ \\
\hline 5 & 65 & $\mathbf{F}$ & 8 & 68 & 60 & 1 & $21 \cdot 9$ \\
\hline 6 & 52 & $\mathbf{F}$ & 1 & 53 & 33 & 2 & $18 \cdot 1$ \\
\hline 7 & 46 & $\mathbf{F}$ & 16 & 50 & 33 & 2 & $19 \cdot 7$ \\
\hline 8 & 53 & $\mathbf{F}$ & 15 & 66 & 62 & 2 & $16 \cdot 3$ \\
\hline 9 & 40 & $\mathbf{F}$ & 30 & 61 & 64 & 2 & $20 \cdot 8$ \\
\hline 10 & 43 & $\mathbf{F}$ & $3 \frac{1}{2}$ & 72 & 75 & 2 & $5 \cdot 3$ \\
\hline 11 & 51 & $\mathbf{F}$ & $1 \frac{1}{2}$ & 74 & 81 & 2 & $22 \cdot 7$ \\
\hline 12 & 38 & $\mathbf{F}$ & 4 & 70 & 34 & 2 & 16.9 \\
\hline 13 & 57 & $\mathbf{F}$ & 5 & 79 & 19 & 1 & $17 \cdot 6$ \\
\hline 14 & 59 & $\mathbf{M}$ & 3 & 87 & 34 & 2 & $21 \cdot 6$ \\
\hline 15 & 58 & $F$ & 3 & 53 & 53 & 1 & $25 \cdot 4$ \\
\hline 16 & 79 & $\mathbf{F}$ & 6 & 58 & 76 & 2 & $13 \cdot 7$ \\
\hline 17 & 51 & $F$ & 1 & 72 & 85 & 2 & $21 \cdot 3$ \\
\hline 18 & 45 & $F$ & 5 & 63 & 72 & 3 & $14 \cdot 0$ \\
\hline & & & Mean & 63 & 61 & & \\
\hline
\end{tabular}




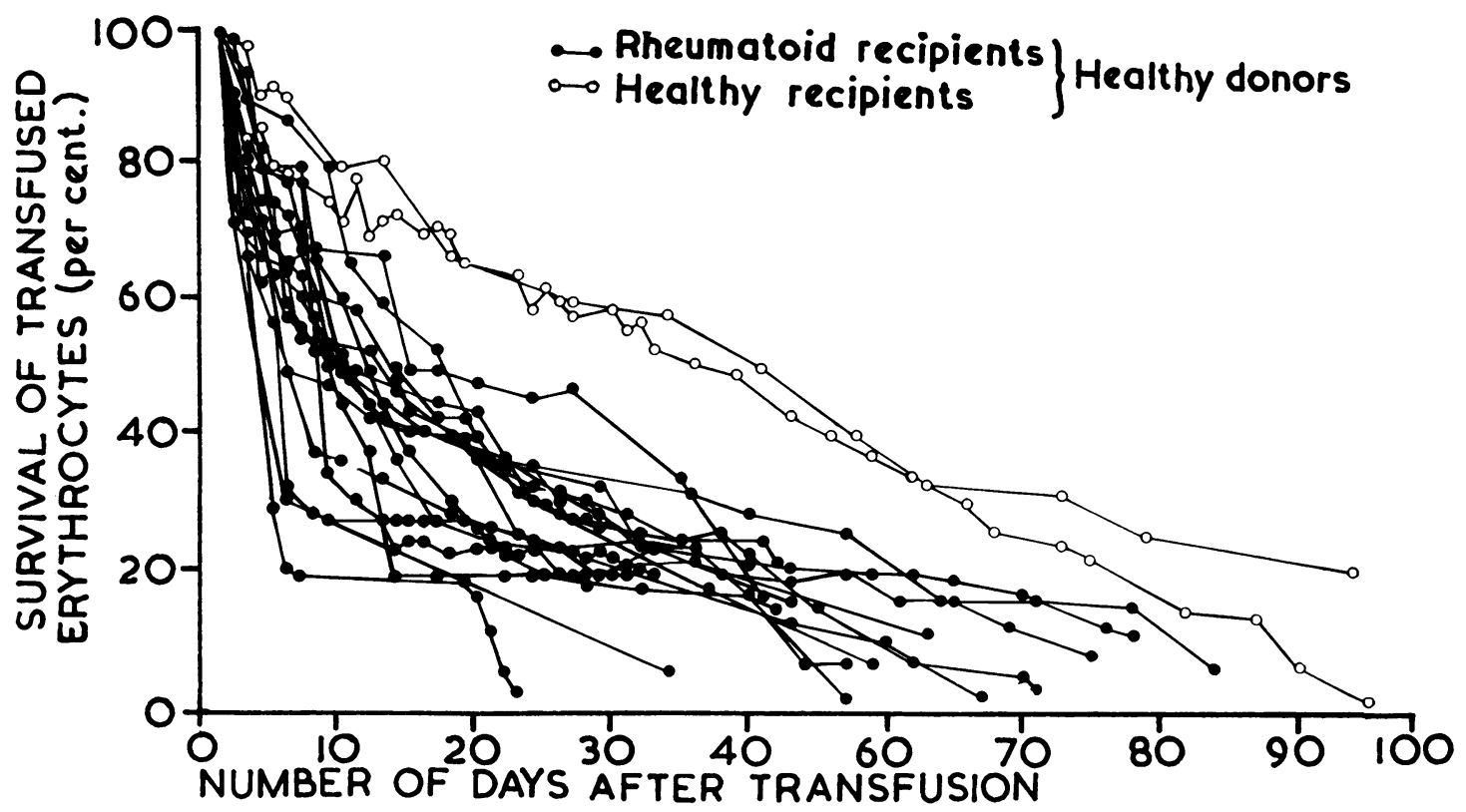

Fig. 1.-Survival of transfused erythrocytes from healthy donors in eighteen patients with rheumatoid arthritis and two healthy controls.

Fig. 1 presents a composite graph showing the rate of elimination of cells transfused from healthy donors to these recipients. The results in two healthy controls are included for comparison. Twelve of the patients were transfused on more than one occasion, but the data given in Fig. 1 refer only to the first transfusion. The nineteenth patient in the series is omitted from Table I and Fig. 1 as rheumatoid cells were given in the first transfusion.

The initial loss of transfused cells in the rheumatoid recipients was abnormally rapid in all cases. Subsequently the rate of destruction became more linear in character, resembling that seen in the controls. The duration of survival of transfused $\overparen{ }$ cells was calculated from the formulae evolved by Brown and others (1944). The figures for mean survival time correspond to the "average life ( $\mathfrak{t}$ days)" used by these authors. In six cases of idiopathic hypochromic anaemia investigated by them the average life ( $\overline{\mathrm{t}}$ days) ranged from $38 \cdot 2$ to 53.9 with a mean of $44 \cdot 8$. The mean survival time for each patient is shown in Table $I$. The average of the means was $17 \cdot 6$ with a standard deviation of $4 \cdot 88$.

No clear relationship between the disappearance rate and the initial degree of anaemia was found,

TABLE II

COMPARISON OF SURVIVAL OF CELLS FROM HEALTHY AND RHEUMATOID DONORS TRANSFUSED TO SEVEN RHEUMATOID RECIPIENTS (GROUP I)

\begin{tabular}{|c|c|c|c|c|c|c|c|c|c|c|c|c|c|}
\hline \multirow{2}{*}{$\begin{array}{l}\text { Case } \\
\text { No. }\end{array}$} & \multirow[b]{2}{*}{ Age } & \multirow{2}{*}{ Sex } & \multirow{2}{*}{$\begin{array}{c}\text { Dura- } \\
\text { tion of } \\
\text { Disease } \\
\text { (yrs) }\end{array}$} & \multicolumn{2}{|c|}{$\begin{array}{l}\text { Before 1st } \\
\text { Transfusion }\end{array}$} & \multirow{2}{*}{$\begin{array}{l}\text { Volume } \\
\text { Trans- } \\
\text { fused } \\
\text { (pints) }\end{array}$} & \multirow{2}{*}{ Donor } & \multirow{2}{*}{$\begin{array}{c}\text { Mean } \\
\text { Survival } \\
\text { Time } \\
\text { (days) }\end{array}$} & \multicolumn{2}{|c|}{$\begin{array}{l}\text { Before 2nd } \\
\text { Transfusion }\end{array}$} & \multirow{2}{*}{$\begin{array}{l}\text { Volume } \\
\text { Trans- } \\
\text { fused } \\
\text { (pints) }\end{array}$} & \multirow{2}{*}{ Donor } & \multirow{2}{*}{$\begin{array}{c}\text { Mean } \\
\text { Survival } \\
\text { Time } \\
\text { (days) }\end{array}$} \\
\hline & & & & $\begin{array}{l}\text { Hb (per } \\
\text { cent.) }\end{array}$ & $\underset{(\mathrm{mm} . / \mathrm{hr})}{\text { E.S.R. }}$ & & & & $\begin{array}{l}\text { Hb (per } \\
\text { cent.) }\end{array}$ & $\underset{(\mathrm{mm} . / \mathrm{hr})}{\text { E.S.R. }}$ & & & \\
\hline 1 & 75 & $F$ & 1 & 73 & 104 & 2 & Healthy & $16 \cdot 4$ & 65 & 89 & 1 & Rheumatoid & $25 \cdot 8$ \\
\hline 2 & 48 & $\mathrm{~F}$ & 12 & 62 & 52 & 2 & Healthy & $19 \cdot 7$ & 68 & 32 & 1 & Rheumatoid & $34 \cdot 1$ \\
\hline 3 & 52 & $\mathbf{M}$ & 4 & 60 & 37 & 2 & Healthy & $17 \cdot 9$ & 82 & 24 & 1 & Rheumatoid & $29 \cdot 1$ \\
\hline 4 & 60 & $\mathbf{M}$ & 2 & 52 & 124 & 2 & Healthy & $7 \cdot 8$ & 64 & 118 & 1 & Rheumatoid & $22 \cdot 9$ \\
\hline 5 & 65 & $F$ & 8 & 68 & 60 & 1 & Healthy & $21 \cdot 9$ & 65 & 81 & 1 & Rheumatoid & $32 \cdot 1$ \\
\hline 18 & 45 & $\mathbf{F}$ & 5 & 63 & 72 & 3 & Healthy & $14 \cdot 0$ & 77 & 61 & 1 & Rheumatoid & $37 \cdot 8$ \\
\hline 19 & 50 & $\mathbf{M}$ & 2 & 77 & 22 & 1 & Rheumatoid & $41 \cdot 4$ & 75 & 71 & 1 & Healthy & $20 \cdot 7$ \\
\hline & & & Mean & 65 & 67 & & & Mean & 71 & 68 & & & \\
\hline
\end{tabular}

Average of mean survival times: healthy cells, $16 \cdot 9$ days; rheumatoid cells, $31 \cdot 9$ days. 


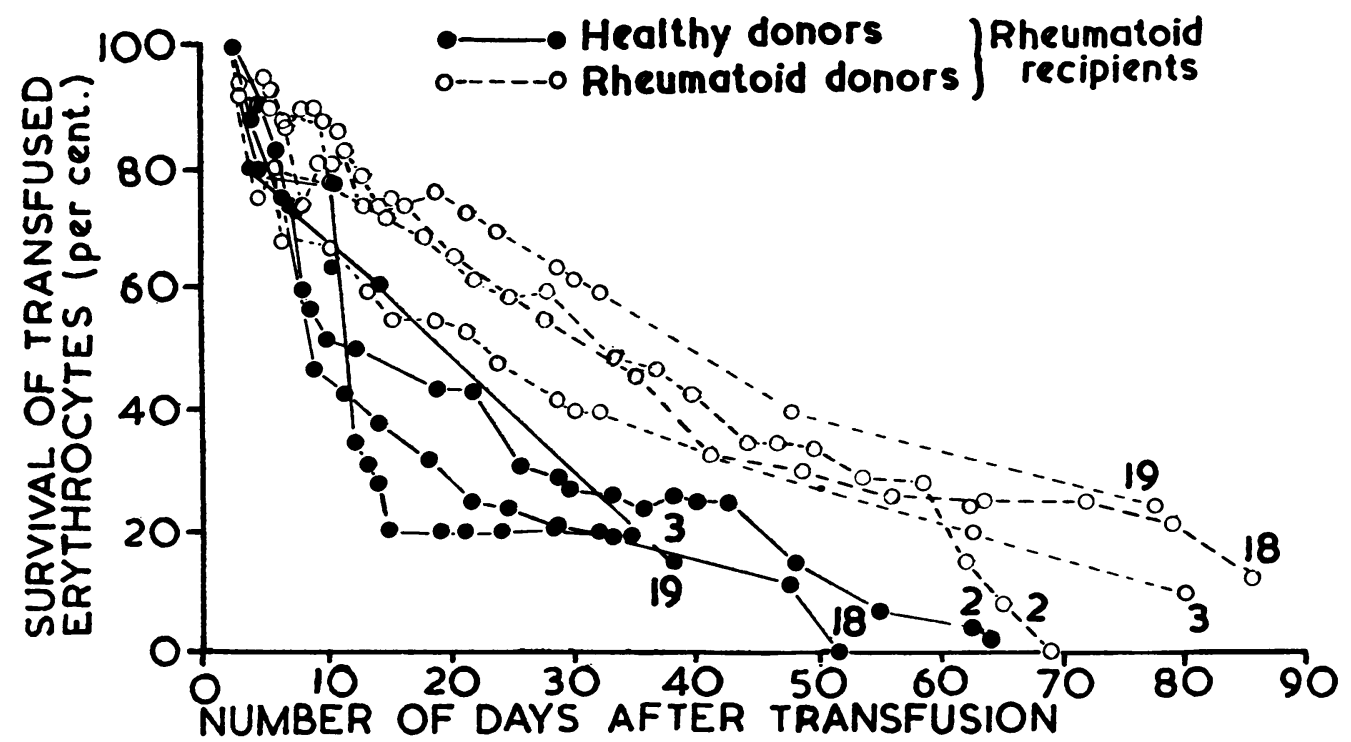

Fig. 2.-Survival of transfused erythrocytes from both healthy and rheumatoid donors in each of four patients with rheumatoid arthritis. (Cases 2, 3, 18, 19).

but in five patients (Cases 1, 4, 9, 10, and 16), where the erythrocyte sedimentation rate before transfusion was $64 \mathrm{~mm}$./hr or more, 50 per cent. of transfused cells had been destroyed in 6 days or less, suggesting a relationship between the activity of the disease and the rate of destruction of transfused cells.

Fourteen patients received cells from 2 pints of blood, three received cells from 1 pint of blood, and the remaining patient was given cells from 3 pints of blood. The number of red cells transfused did not appear to influence the total duration of survival or the shape of the curves recorded in this group of patients.

Comparison of Survival of Red Cells from Healthy Donors and Rheumatoid Donors in Individual Patients

Group I.-Seven patients received two transfusions, one from a healthy and one from a rheumatoid donor. One patient (No. 19) received cells from a rheumatoid donor first; the other six received healthy cells before rheumatoid cells.

Table II includes details of the age, sex, and clinical status of the seven recipients in Group I. Elimination rates of cells from healthy and rheumatoid donors in four of these patients are given in Fig. 2. For the sake of clarity comparative curves obtained from the other three patients in the group have been omitted, but the curves in all seven have been analysed and will be discussed below. In all seven patients the initial destruction of transfused cells was less rapid when rheumatoid cells were given, although strictly normal linear decay was not observed.

Mean survival times following the first and second transfusions is shown in Table II. The average of the mean survival times following the transfusion of cells from healthy donors was 16.9 days in contrast to that following the transfusion of cells from rheumatoid donors which was 31.9 days. The difference between the averages was 15 . The standard error of the difference was $3.07\left(\frac{\text { Difference }}{\text { S.E. of Difference }}=4.88 ; P<0.01\right)$. The difference is therefore highly significant.

Group II.-It might be argued that the more prolonged survival of the cells from rheumatoid donors could be accounted for by improvement in the clinical condition of the recipients following the first transfusion from healthy donors. To test this possibility seven other patients were given two consecutive transfusions from healthy donors. Details of the clinical status of patients before each transfusion are given in Table III (overleaf). The average mean survival time after the first transfusion was $17 \cdot 1$ days; after the second transfusion it was 21.9 days. The difference between the averages was $4 \cdot 8$. The standard error of difference was $4 \cdot 30\left(\frac{\text { Difference }}{\text { S.E. of Difference }}=1 \cdot 11 ; P>0.05\right)$. The difference was not significant.

As an additional check the average mean survival time following a total of 26 transfusions of healthy cells to nineteen rheumatoid recipients was calculated and was found to be $19 \cdot 1$ days $\pm 1 \cdot 3$. The figure of 16.9 days in Group $I$ is therefore representative of the whole series.

In two patients in Group II (Cases 6 and 9) survival following the second transfusion was significantly prolonged; $18 \cdot 1$ to $33 \cdot 6$ days and $20 \cdot 8$ 
TABLE III

COMPARISON OF SURVIVAL OF CELLS FROM HEALTHY DONORS AFTER TWO TRANSFUSIONS TO SEVEN RHEUMATOID RECIPIENTS (GROUP II)

\begin{tabular}{|c|c|c|c|c|c|c|c|c|c|c|c|}
\hline \multirow{2}{*}{$\begin{array}{l}\text { Case } \\
\text { No. }\end{array}$} & \multirow[b]{2}{*}{ Age } & \multirow{2}{*}{ Sex } & \multirow{2}{*}{$\begin{array}{c}\begin{array}{c}\text { Duration } \\
\text { of } \\
\text { Disease } \\
\text { (yrs) }\end{array} \\
\end{array}$} & \multicolumn{2}{|c|}{ Before 1st Transfusion } & \multirow{2}{*}{$\begin{array}{l}\text { Volume } \\
\text { Trans- } \\
\text { fused } \\
\text { (pints) }\end{array}$} & \multirow{2}{*}{$\begin{array}{c}\text { Mean } \\
\text { Survival } \\
\text { Time } \\
\text { (days) }\end{array}$} & \multicolumn{2}{|c|}{ Before 2nd Transfusion } & \multirow{2}{*}{$\begin{array}{l}\text { Volume } \\
\text { Trans- } \\
\text { fused } \\
\text { (pints) }\end{array}$} & \multirow{2}{*}{$\begin{array}{c}\text { Mean } \\
\text { Survival } \\
\text { Time } \\
\text { (days) }\end{array}$} \\
\hline & & & & $\begin{array}{c}\mathrm{Hb} \\
\text { (per cent.) }\end{array}$ & $\begin{array}{c}\text { E.S.R. } \\
(\mathrm{mm} . / \mathrm{hr})\end{array}$ & & & $\begin{array}{c}\mathrm{Hb} \\
\text { (per cent.) } \\
\end{array}$ & $\begin{array}{c}\text { E.S.R. } \\
\text { (mm./hr) }\end{array}$ & & \\
\hline 6 & 52 & $\mathbf{F}$ & 1 & 53 & 33 & 2 & $18 \cdot 1$ & 79 & 43 & 2 & $33 \cdot 6$ \\
\hline 7 & 46 & $F$ & 16 & 50 & 33 & 2 & $19 \cdot 7$ & 75 & 20 & 2 & $13 \cdot 2$ \\
\hline 8 & 53 & $\mathbf{F}$ & 15 & 66 & 62 & 2 & $16 \cdot 3$ & 74 & 47 & 2 & $15 \cdot 6$ \\
\hline 9 & 40 & $\mathbf{F}$ & 30 & 61 & 64 & 2 & $20 \cdot 8$ & 61 & 12 & 2 & $37 \cdot 5$ \\
\hline 10 & 43 & $\mathbf{F}$ & $3 \frac{1}{2}$ & 72 & 75 & 2 & $5 \cdot 3$ & 64 & 125 & 2 & $11 \cdot 2$ \\
\hline 11 & 51 & $\mathbf{F}$ & $1 \frac{1}{2}$ & 74 & 81 & 2 & $22 \cdot 7$ & 90 & 25 & 1 & $23 \cdot 4$ \\
\hline 12 & 38 & $\mathrm{~F}$ & 4 & 70 & 34 & 2 & $16 \cdot 9$ & 82 & 26 & 2 & $18 \cdot 6$ \\
\hline & & & Mean .. & 64 & 55 & & Mean .. & 75 & 42 & & \\
\hline
\end{tabular}

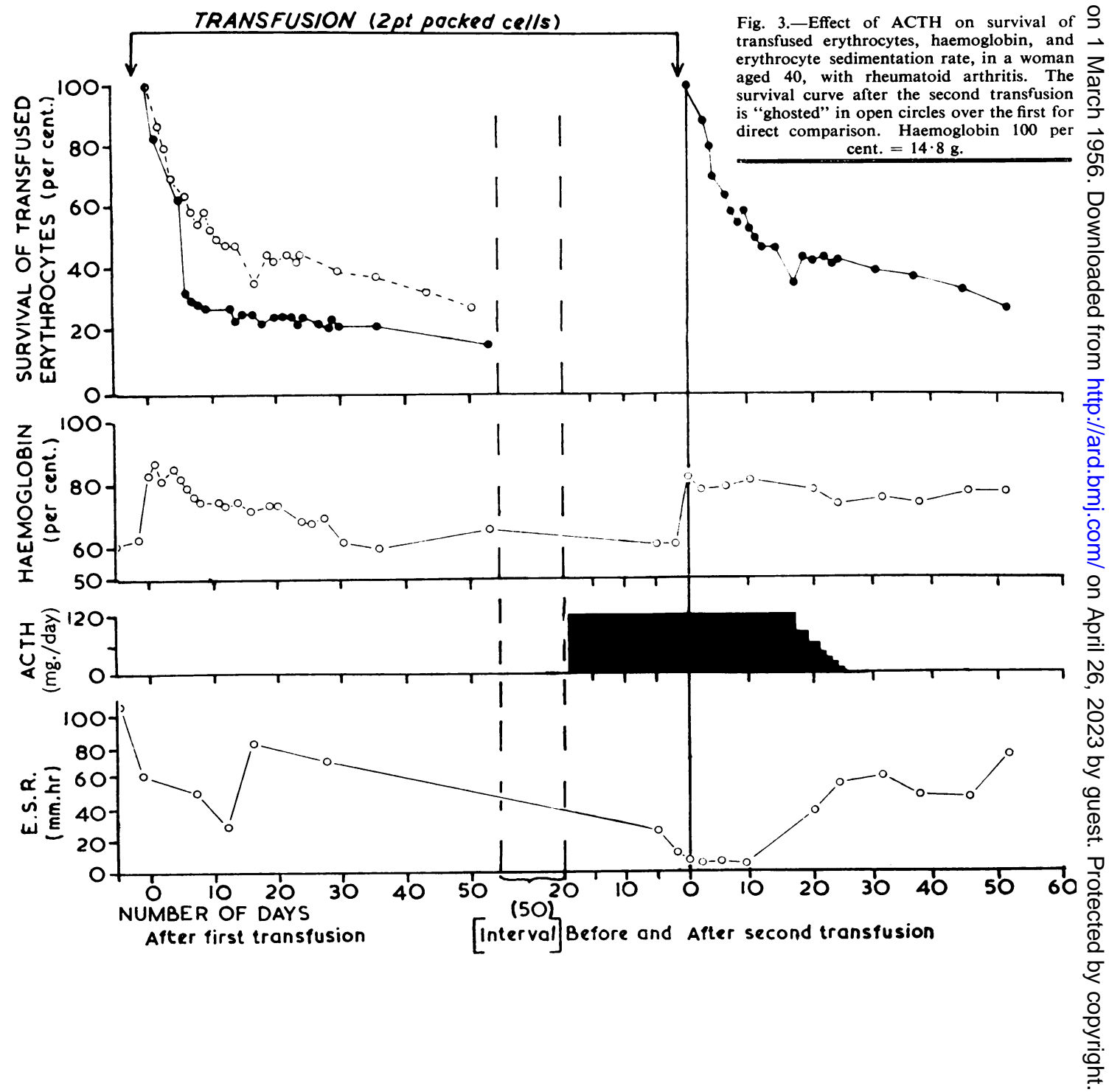


to $37 \cdot 5$ days respectively. In one patient (Case 6) the haemoglobin level had risen from 53 to 79 per cent. following the first transfusion, but there was no significant change in the erythrocyte sedimentation rate. In the second patient (Case 9), although the haemoglobin level was unchanged, the erythrocyte sedimentation rate had fallen from 64 to $12 \mathrm{~mm}$./hr after the first transfusion. The results in these two patients do not alter the significance of the findings in the group as a whole.

Effect of ACTH on Survival of Red Cells transfused from Healthy Donors. - Two patients belonging to Group II were given suppressive doses of ACTH before the second transfusion of cells from healthy donors.

Fig. 3 shows the survival curves after each transfusion in the first patient. Although adequate clinical suppression was attained and the erythrocyte sedimentation rate became normal just before the second transfusion, the initial disappearance rate of the transfused cells was equally rapid after both transfusions. The slope of elimination became less steep on the tenth day after the second transfusion, but the overall shape was unaltered.

In the second patient to whom ACTH was administered, complete suppression of signs of the disease was not achieved with the dose given. The erythrocyte sedimentation rate did not return to normal although the patient was free from symptoms (Fig. 4). Disappearance of cells after the first transfusion was very rapid and after the second the rate was not materially altered by the administration of ACTH.

Effect of Intravenous Iron on Survival of Cells transfused from Healthy Donors.-Three patients in Group II were given $2 \mathrm{~g}$. saccharated oxide of iron intravenously before the second transfusion. The iron was administered to one patient immediately before transfusion and no prolongation of cell survival was observed.

In the other two patients the second transfusion was delayed until haematological improvement had occurred. In one of these (Fig. 5, overleaf) the haemoglobin had risen from 50 to 75 per cent. in 60 days. The other (Fig. 6, overleaf) showed only moderate improvement after iron administration; although the red cell count rose by $1 \cdot 2$ million/c.mm., the haemoglobin only increased by 8 per cent. In neither patient was cell survival prolonged after the second transfusion.

\section{Discussion}

The results of this investigation have shown that, in active rheumatoid arthritis, the rate of elimination from the circulation of red cells transfused from healthy donors is abnormal. The initial disappearance of healthy cells is rapid, elimination thereafter approximating to the linear mechanism of normal senescence. When cells from rheumatoid 

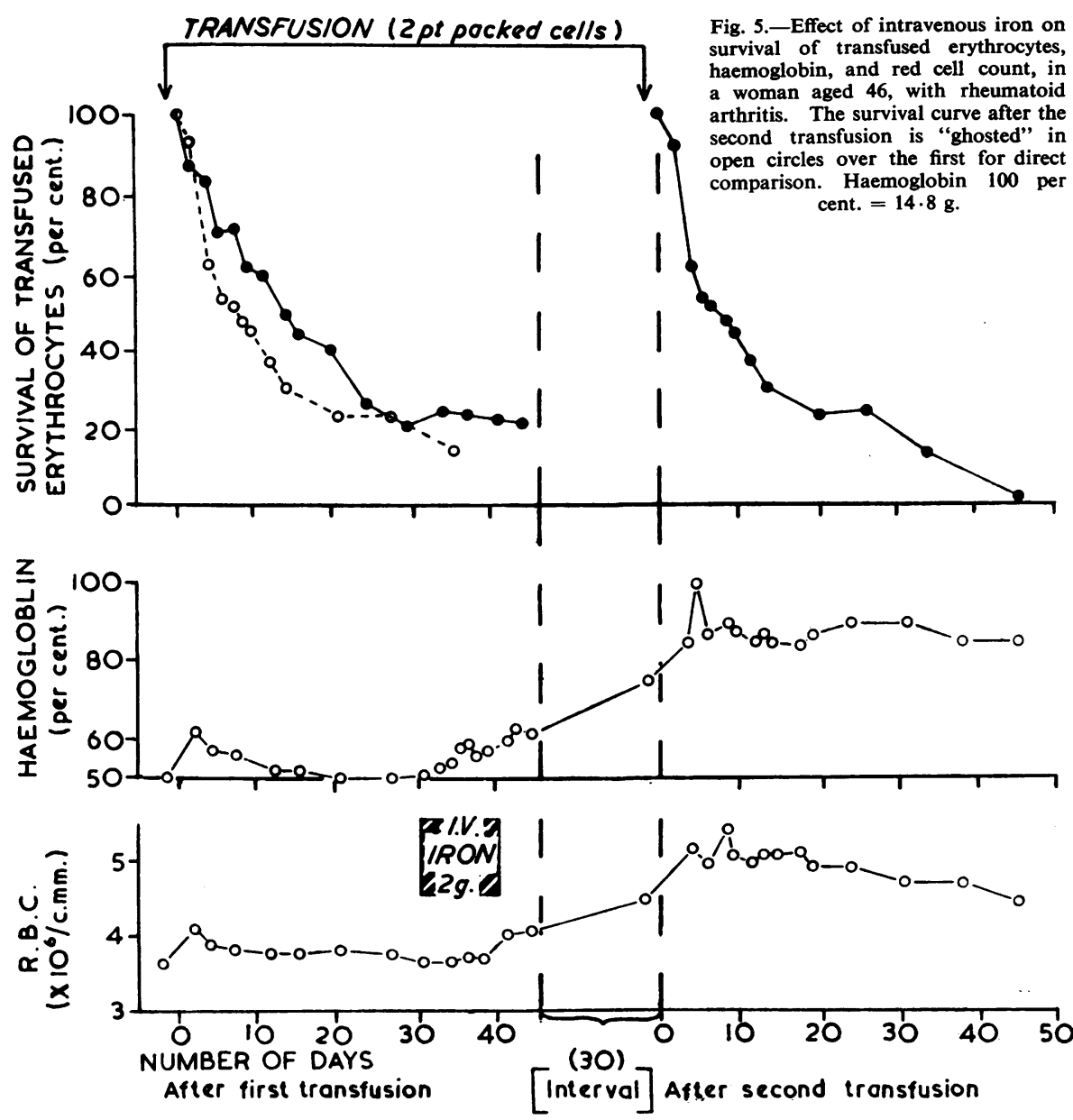

rheumatoid cells $\frac{5}{3}$ in healthy recip- 므 ients reported by Freireich and $\vec{F}$ others (1954) does not exclude this $\frac{\square}{0}$ possibility, as $\overline{\bar{N}}$ Loutit and Molli- $\mathbb{D}$ son (1946) have shown that red $s$ cells from four $\overrightarrow{0}$ patients suffering $\overrightarrow{\vec{H}}$ from acquired haemolytic anaemia survived nor- ?. mally in healthy $\vec{v}$ recipients.

Overactivity of $\vec{N}$

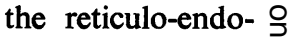
thelial system $\rightarrow$ could account for 3 increased red cell destruction. There is reason to believe, $\bar{c}$ from pathological os studies and from recent experiments with intravenous iron, that the reticulo-endothelial system is overactive in rheumatoid arthritis. Such a state of affairs can- $\frac{\vec{F}}{0}$ not explain the difference in the

patients are transfused, overall elimination is less rapid and initial disappearance more gradual.

These results suggest that increased cell destruction may be one factor in the causation of anaemia in rheumatoid arthritis, but, in view of the persistent hypochromia of the red cells and the absence of clinical evidence of haemolysis, it is unlikely that this is the only factor concerned. Accurate interpretation of Ashby curves is difficult, but the rapid initial elimination of healthy cells, followed by almost linear decay, might be explained by an increased susceptibility to destruction of a proportion of the transfused cells. Such susceptibility could only be "acquired" after transfusion and would suggest the presence of a sensitizing agent in the circulation of the recipient which is taken up by a proportion of the transfused cells. In these circumstances the unsensitized cells would be eliminated by normal senescence. The normal survival of rate of elimination of healthy and rheumatoid cells $\dot{0}$ in the rheumatoid patient unless at the same time it is postulated that cells from patients with rheuma- 8 toid arthritis are less susceptible to destruction than cells from healthy donors.

Detailed studies of red cells from rheumatoid patients are in progress, with the aim of defining any physical or immunological characteristics which might explain their ability to survive longer than of normal red cells in the circulation of patients with $N$ rheumatoid arthritis, but at the moment no explana- N tion of this phenomenon can be offered.

The administration of short courses of ACTH in doses sufficient to control clinical symptoms has not $\frac{2}{D}$ materially influenced the survival of cells transfused $\stackrel{\mathcal{\infty}}{\rightarrow}$ from healthy donors. This would suggest that the 0 factor or factors responsible for decreased survival are not directly influenced by adrenal stimulation.

Improvement in the blood picture after the $\overrightarrow{\mathbb{D}}$ 


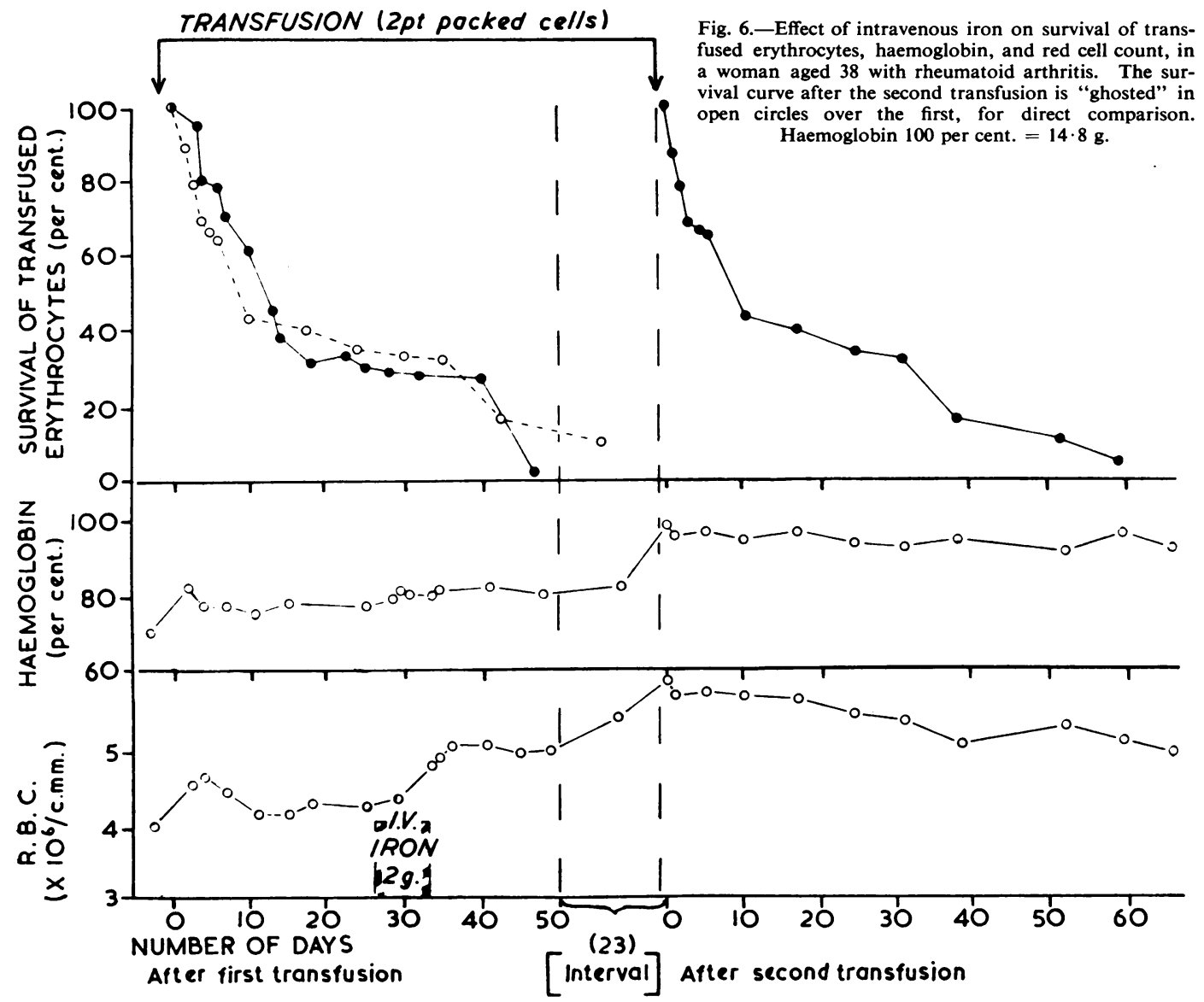

administration of intravenous iron has not been followed by more prolonged survival of normal cells in these patients.

It would appear that more than one mechanism may be responsible for the production of anaemia in rheumatoid arthritis. Hypochromia of the red cells may arise from defective synthesis of haemoglobin in the marrow, which may be related to the abnormal metabolism of iron. Reduction in the red cell count may be due in part at least to increased destruction of the patient's own erythrocytes by cells of the reticulo-endothelial system.

\section{Summary}

(1) Erythrocytes from healthy donors are eliminated from the circulation with abnormal rapidity in patients suffering from rheumatoid arthritis.

(2) Erythrocytes from rheumatoid donors survive longer in rheumatoid recipients than cells from healthy donors.
(3) Consecutive transfusions from healthy donors do not as a rule influence the speed with which these cells are destroyed in patients with rheumatoid arthritis.

(4) The administration of ACTH in doses sufficient to suppress the clinical signs of the disease does not prolong the survival of normal erythrocytes in rheumatoid recipients.

(5) Haematological improvement after the administration of intravenous iron is not accompanied by increased survival of normal erythrocytes in rheumatoid recipients.

We wish to record our sincere gratitude to Dr. R. A. Cumming, Blood Transfusion Service, Edinburgh Royal Infirmary, who supplied blood from healthy donors and anti-sera for differential agglutination. He also made himself responsible for direct cross-matching of blood from donors and recipients, and was available at all times with expert advice. We also wish to express our thanks to Dr. P. E. Brown, of the Department of Public Health 
and Social Medicine, Edinburgh University, for statistical help, and to Miss Jane Hurst and Miss Dorothy Anderson, haematological technicians, Rheumatic Unit, for their accurate and painstaking work throughout the investigation.

Throughout the period when this work was done, the Rheumatic Unit was in receipt of grants from the Nuffield Foundation, the Medical Research Council, and Boots Pure Drug Company. One of us (W.R.M.A.) was the holder of the Hastilow Research Scholarship in Rheumatism, awarded by the University of Edinburgh.

\section{REFERENCES}

Ashby, W. (1919). J. exp. Med., 29, 267.

Brown, G. M., Hayward, O. C., Powell, E. O., and Witts, L. J. (1944). J. Path. Bact., 56, 81.

Bunim, J. J. (1954). Annals of the Rheumatic Diseases, 13, 365. Freireich, E. J., Ross, J. F., Bayles, T. B., Emerson, C. P., and Finch, S. C. (1954). Ilbid., 13, 365.

Loutit, J. F., and Mollison, P. L.' (1946). J. Path. Bact., 58, 711.

Mollison, P. L., and Paterson, J. C. S. (1949). J. clin. Path., 2, 109.

Roy, L. M. H., Alexander, W. R. M., and Duthie, J. J. R. (1955). Annals of the Rheumatic Diseases, 14, 63.

\section{Nature de l'anémie dans l'arthrite rhumatismale}

RÉSUMÉ

(1) Les érythrocytes des donneurs sains sont éliminés de la circulation avec une vitesse anormale chez des malades atteints d'arthrite rhumatismale.

(2) Les érythrocytes des donneurs rhumatismaux survivent plus longtemps que les globules des donneurs sains chez les réceveurs rhumatismaux.
(3) Des transfusions consécutives de donneurs sains n'influencent pas d'ordinaire la vitesse de la destruction chez les rhumatisants.

(4) L'administration de l'ACTH en doses suffisantes pour supprimer les signes cliniques de la maladie ne prolongent pas la vie des érythrocytes normaux chez les réceveurs rhumatisants.

(5) L'amélioration hématologique après l'administration intraveineuse de fer ne s'accompagne pas d'une prolongation de la vie des globules rouges normaux chez les réceveurs rhumatisants.

Naturaleza de la anemia en la artritis reumatoide Sumario

(1) Los eritrocitos de los dadores sanos se eliminan de la circulación con una velocidad anormal en enfermos con artritis reumatoide.

(2) Los eritrocitos de los dadores reumáticos sobreviven más tiempo que los glóbulos de los dadores sanos en los receptores reumáticos.

(3) Transfusiones consecutivas de dadores sanos no afectan generalmente la velocidad de la destrucción en los reumáticos.

(4) La administración de la ACTH en dosis suficientes para suprimir las manifestaciones clínicas de la enfermedad no prolonga la vida de los eritrocitos normales en los receptores reumáticos.

(5) La mejoría hematológica después de la administración endovenosa de hierro no se acompaña de una prolongación de la vida de los eritrocitos en los receptores reumáticos. 